\title{
CEREBRAL SYSTEMS IN THE PATHOGENESIS OF ENDOGENOUS PSYCHOSES*
}

\author{
ANIBAL SILVEIRA**
}

\begin{abstract}
Mental process imply a harmonious functioning of psychic systems, assembled into larger units, psychic spheres (Table 1). Their neurophysiological representatives are brain systems of areas and pathways (Figs 1-4). Under functional and/or organic disturbances these systems originate the leading mental symptoms (Table 2) characterizing the diverse endogenous psychoses: hence, the latter's distinctive patterns. Accordingly, understanding and classification of psychoses should rest on the pathogenic dynamisms, not on clinical description. This is why Kleist's and Leonhard's conceptions of the endogenous psychoses surpass any other to exist. Kleist stands among the founders of psychiatry, by describing the "degeneration psychoses" and many single psychoses, as well as redefining, isolating and clarifying the progressive ones, later on renamed as schizophrenias (Table 3). Such pathogenic criterion may also be useul to define mental conditions other than psychoses, as hysteria, neuroses and psychopathic inferiority (Tables 4 and 5). One should consider here, besides the psychic systems and spheres involved, the way they were caught and the corresponding developmental phase. In Kleist's "degeneration psychoses"- cyclic or episodic (Table 6) the systems and spheres are disturbed by functional transient processes due to latent dispositions, while his and Leonhard's schizophrenias (Table 7) show a rather progressive, deteriorating course. The nature of the disorder is itself genetically determined, as is either its confinement to one sphere or its spreading out. The spread out pattern, while exceptional in schizophrenia, represents a rule for the "degeneration psychoses", in discussant's mind. Both groups may have symptoms alike by involvement of the same sphere (Table 8), but proper diagnosis is reached by taking pathogenesis into consideration.
\end{abstract}

KEY WORDS: mental disorders, endogenous psychoses, cerebral systems.

\section{Sistemas cerebrais na patogênese de psicoses endógenas}

RESUMO - Os processos mentais implicam em funcionamento harmônico de sistemas psiquicos, os quais se reunem em unidades mais amplas, as esferas psíquicas (Tabela 1). A eles correspondem, no plano neurofisiológico, sistemas cerebrais formados por áreas e fibras que as interligam (Figs 1-4). Em condições patológicas, orgânicas ou funcionais, tais sistemas originam os sintomas principais (Tabela 2) que caracterizam as diversas psicoses endógenas: daí o quadro clínico que as distingue entre si. Nessas condições, a compreensão e a classificação das psicoses deveriam basear-se no dinamismo patogênico e não na descrição clínica. E é por isto que as concepções de Kleist e de Leonhard sobre as psicoses endógenas ultrapassam o valor de quaisquer outras. Kleist figura entre os fundadores da psiquiatria ao criar o grupo das "psicoses degenerativas"e várias psicoses isoladas, bem como ao definir, isolar e esclarecer o conjunto das psicoses progressivas que mais tarde redenominou esquizofrenias (Tabela 3). Tal critério patogenético pode também ser útil para a definição de quadros clínicos mentais que não são psicoses, tais a histeria, as neuroses em geral, as personalidades psicopáticas (Tabela 4 e 5). Neste domínio, haveria a considerar, na patogênese, tanto as esferas e os sistemas mentais, quanto o modo pelo qual foram desorganizados e a fase de desenvolvimento em que se encontravam. Nas "psicoses degenerativas" de Kleist sejam cíclicas, sejam episódicas (Tabela 6) - as esferas e os sistemas são alterados por processos funcionais transitórios devidos a disposições genéticas latentes, ao passo que as esquizofrenias dele e de Leonhard (Tabela 7) decorrem em geral de modo progressivo e levam à decadência mental. A própria desordem é de natureza genética, como também o fato de se limitar a determinada esfera psíquica ou de se propagar a mais de uma. Os

*Primeiramente publicado em Arq Neuropsiquiatr 1962;20:263-278. Republicação em Homenagem do texto revisto pelo próprio autor em 1974.

**Lecturer in Psychiatry at the Faculty of Medicine and Professor of Psychopathology at the Faculty of Philosophy, Sciences and Letters, University of São Paulo, Brazil. Presented on the 6th June, 1961, at the 3rd World Congress of Psychiatry, Montreal, Canada (Professor Leonhard's Symposium on Atypical Endogenous Psychoses). 
quadros clínicos em que ocorre esta propagação são excepcionais na esquizofrenia ao passo que constituem a regra nas "psicoses degenerativas", na nossa opinião. Ambos estes grupos mórbidos podem ter sintomas clínicos em comum pelo fato de estar atingido o mesmo sistema cerebral (Tabela 8), mas o diagnóstico clínico poderá ser estabelecido corretamente se a patogênese for levada em conta.

PALAVAS-CHAVE: desordens mentais, psicose endógenas, sistemas cerebrais.

We believe that the psychiatrist, by the same reason as the specialist in projective techniques, cannot achieve progress without following a theory of personality. The psychoanalytical one, which is in favor almost ererywhere in the Western Hemisphere, may explain the abnormal dynamisms in the neuroses and other conditions alike. However, it does not apply to the psychoses, at least to the great majority of them, and leaves aside, as we feel it, many psychological aspects of mind's growing processes. The same restriction seems to apply to the few other theories of personality developed more recently. If we wicsh a theory that may encompass all of the normal and abnormal mental conditions and take in due account their relations to brain physiology and pathology we have to proceed until as far back as 1850. Such theory was founded by one the foremost thinkers of all times, the French philosopher Auguste Comte, who espounded it in $1851^{4}$. It was later on elaborated remarkably by the philosopher and physician Georges Audiffrent in two large volumes, "Du cerveu et de 1'innervation", $1869^{1}$ and "Maladies du cerveau", 1874 . We cannot enter here, of course, into details on such conception of the human mind. Suffice it to say that it was grounded "on sociologial appreciation of Man, on comparative anatomy of the nervous system, on the laws of biology, especially physiology, and verified through animal behavior and pathological anatomy of the brain" (Audiffrent ${ }^{2}$ ). In addition this doctrine described minutely, for the first time, in 1850, the sleep as a biological function of selfpreservation drive, which every scientist now admits, and on the other hand gave the theory of dream in the same precise manner as it was rediscovered some forty years later by Freud. Just a quotation. Stating that vegetative stimuli and instinctual drives prevail in the mind during sleep, hence the dream meaning, Comte says: "Such is the principle by force of which the science of Man (the Moral) will be able to render systematic the subjective interpretation of dreams in order to regulate their course through convenient impressions, cerebral or bodily" (vol. 4,240. Parenthesis and italics are ours) ${ }^{4}$. That was in 1854.

According to that theory, human mind consists of three interdependent spheres - Affectivity, Activity and Interdependent - what is now a truism but at the time was not accepted generally. While working together so close that we cannot separate one from each other in the normal state, they maintain a hierarchy, so that the former is basic and he last named the most dependent; in addition, the affective one influences the other two recently and is "fired" back by the intellectual, but not by the active or conative; activity mediates the affective stimuli towards the intelligence and also receives the regulation from it. On the other hand, each sphere divide itself in several functions - 18 induvidual ones altogether. Comte named them by the current terminology, avoiding to coin new terms and limiting himself deliberately to redefine the old denominations as to adapt to the new concepts. In the affective sphere there are two different levels, the one directed towards personal needs, or instinctual drives properly, and the other aiming at social adaptation; from the former impulsion, a group of three provide the preservation 1) of the self - nutritive, and 2) of the species: sexual and maternal or of possession; two other groups of two drives each are related to 1) the improvement of the individual, namely, the destructive and the constructive, and 2) the ambition - of domination, or pride and of approval, or vanity. The social feelings, or altruism, were called attachment, veneration and kindness, terms that are self descriptive. Three individual functions, firmness, courage and prudence, compose the activity - a general term that corresponds exactly to that of conation, coined by McDougall ${ }^{18}$; such conative dispositions reflect themselves on the explicit action as well as on the working out of the intelligence. This last dominion corresponds to three different levels of contact with the oute - or also with the inner-world: contemplation or observation - be it concrete or abstract, resulting in notions; meditation, deductive or inductive, performing the active thinking proper; and 
Table 1. A tentative scheme of psychic systems after Comte's theory ${ }^{1,2,4}$. All the functions are so arranged as to have the basic ones at the bottom and the most dependent on the top of each column; in addition, dependency and differentiation grow from left to right within the affective sphere and in the reverse direction within conception sector of the intellectual one.

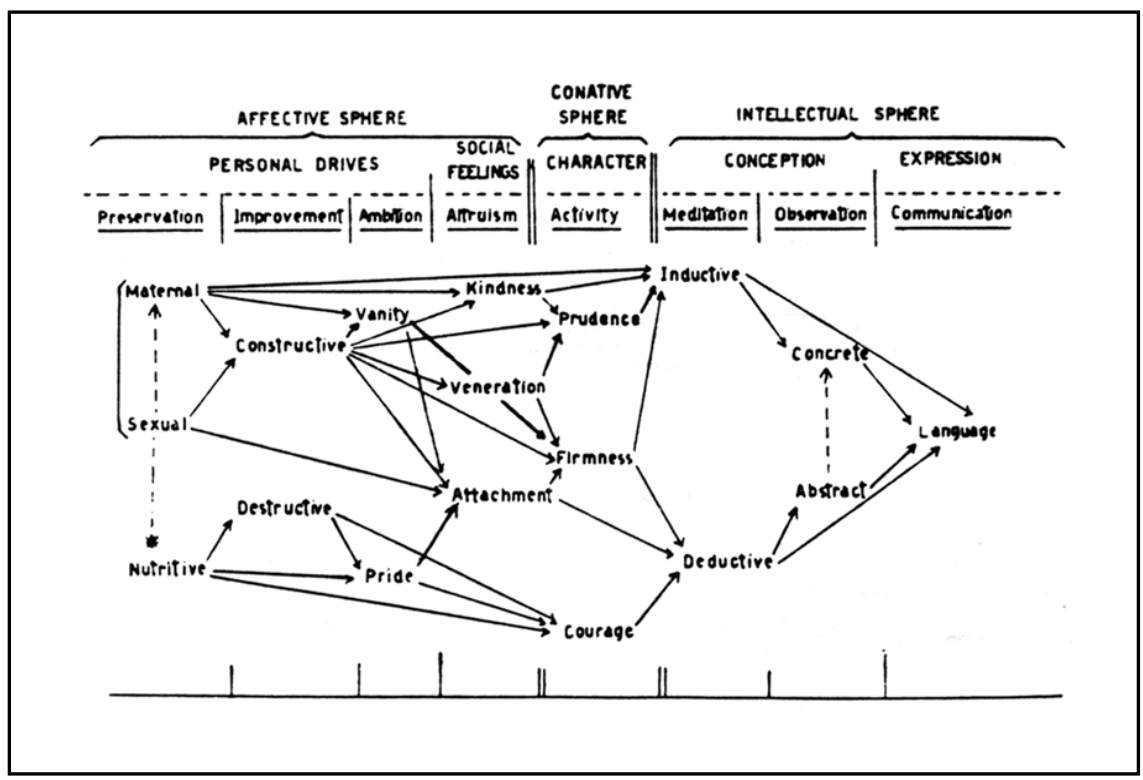

the communication, providing not only the expression for the inner status but also the "signs"that render the abstract constructions possible. The connections between the three spheres of personality just mentioned are not indiscriminate. Much on the contrary, the individual functions maintain selective relationships, so that impulses from one go to only some of the others, at least in a direct manner. Thus, as pointed by Comte and especially by Audiffrent ${ }^{1,2}$, they result in psychic systems. A tentative scheme of these is seen on Table 1, in order to shorten this digression.

One of the most important and remarkable point in Comte's theory of personality is that each individual function represents the working out of a distinct organ, so that to the several functional interrelationships underly a great many deal of paths. Guided by the subjective method, that is, proceeding from the whole to the parts - the meaning of which may only be understood after the functions to be perfomed - Comte located the organs of nutritive and sexual drives on the cerebellar cortex, and all the others on the brain cortex: thus, for the former two and most powerful instinctual motivations the conveying paths are the trans-hemispherical fibers: paleocerebellar and paleocerebral, neocerebellar and neocerebal pathways, both of which spread all over the brain cortex passing through the undercortical relays. Comte specifically states that only the number, the relative positions, and the mutual relationships of such organs could be determined by the subjective method, the real areas and the definite configurations of them depending on objective, anatomo-clinical researches. However, the architectonic methods and, more recently, neurophysiological researches came to support the philosopher views. We must emphasize, in this connection, that all the mental - or subjective functions, after Comte, result from organs located on the cortex, but these relate themselves mutually by means of cortico-cortical, transcallosal and trans-hemispherical pathways, including in the systems, definitely, subcortical structures. As for the cortico-cortical, be it intrahemispherical or transcallosal, the great many deal of researches on neuronography - see for instance those of Dusser de Barenne school ${ }^{3,17}$ among many others - provide evidence of the organizational arrangement of areas; and, as shown on Figure 1, taken from Fulton ${ }^{7}$, occipital, frontal and temporal areas are interconneted by specifical 

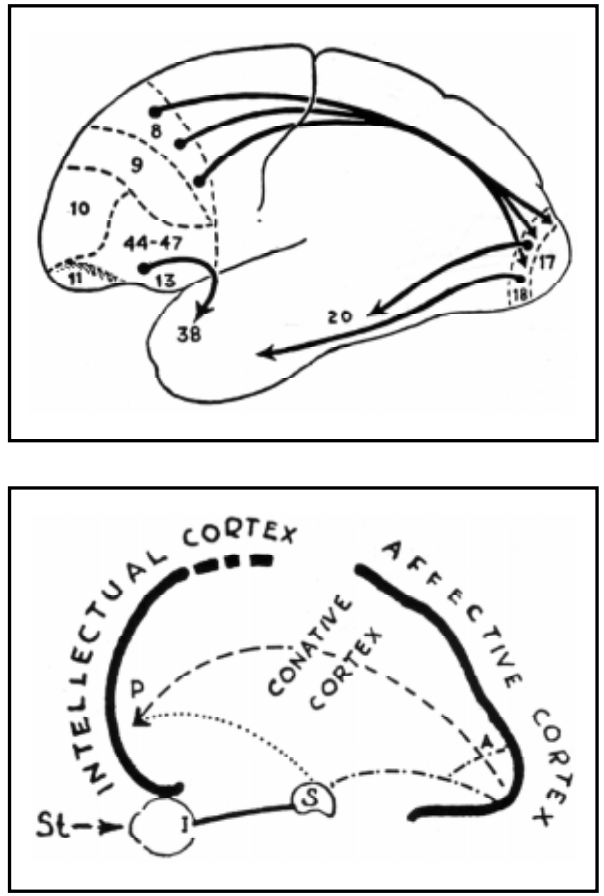

Fig 1. Cortico-cortical connections, particularly between areas 8 an 18. (Taken from Fulton ${ }^{7}$, by courtesy of the author and W.W. Norton \& Norton Inc., New York).
Fig 2. Psycological processes of perception, as exemplified by the visual sense. St, stimulus; I, impression; S, sensation; A, affective; unconscious reaction to conveyed stimulus; $P$, perception; dotand-dash line, path uniting sensorial nucleus and affective cortex, in this case optic radiation plus fibers going to area 19; dotted line, connection to frontal cortex - not yet demonstrated anatomically; broken line, occipital-frontal paths. Intracerebral pathways substantiate what we call the "principle of Audiffrent ${ }^{22}$ " (Courtesy of Hermann \& Cie., Èditeurs, Paris).

pathways. These occipito-frontal fibers represent, according to "Audiffrent's principle" as we call $\mathrm{it}^{22}$, the cortical level involved in vision. The process of perception of visual stimuli - a particular case of perception in any sensory dominion - requires first their transmission to the subcortical nucleus, where they are developed into "sensation" (Fig 2, S); then from here in two directions to the affective and the intellectual cortices at a time; and finally the conveying of the impulse from the affective through the conative cortex towards the intellectual organ of abstract observation ( $\mathrm{P}$ for perception, in Fig 2).

Another beautiful demonstration of the trans-hemisferical system - predicted precisely by Comte and Audiffrent - we have in the recent researches on the reticular formation: both inhibition and facilitation, relayed at the reticular level, are depicted in the known scheme of Magoun ${ }^{16}$ shown in Figure 3. On the other hand, the flowing of the inhibitory processes through the medial and outer cortex follows a definitive path, studied by McCulloch and the group of Dusser de Barenne ${ }^{3,17}$, and which we tried to represent in Figure $4^{23}$.

This interweaving of cortical and undercortical structures, imperative in any mental operation, explains the so called holistic interpretation of mental functioning, but at the same time disprove it, in our mind. The unity is only apparent, since in the normal state all the functions are intimately related one another. However, under pathological conditions the participation of each one may be evidenced in the end result of the abnormality. Indeed, this conception of brain systems as underlying psychic systems, may be useful - sometimes of utmost value as it is, for instance, the case of the deep psychopathological analysis made by Kleist ${ }^{10,12}$. We must bear in mind these dynamisms, in which the most dependent functions, those of the intellectual sphere, are regulated by the ones on the conative and affective spheres. This in turn, translated into neurophysiological terms, would mean regulation of the frontal lobe from the other brain regions of the convexity. Applying this reasoning in studying the clinical patterns of patients with psychic disturbances related to brain lesions directly or indirectly some collaborators and we were able to find a number of frontal lobe symptoms as a result of distant processes, 

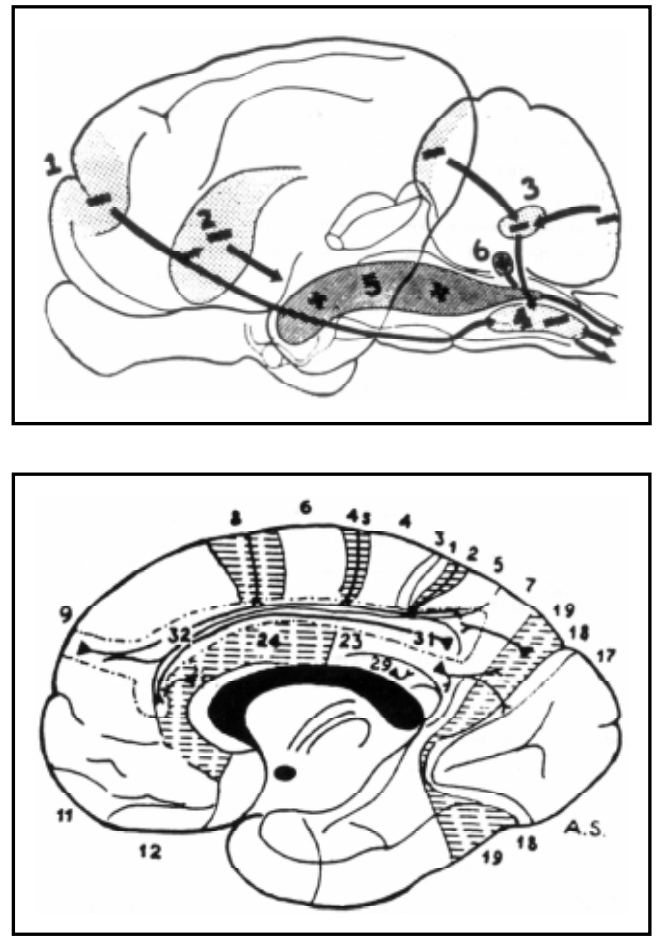

Fig 3. Inhibition and facilitation of cortical activity as mediated by cerebello-and cortico-reticular pathways. (Taken from Magoun ${ }^{16}$, by courtesy of the author and Charles C. Thomas, Publisher, Springfield, Illinois).
Fig 4. Schematic representation of medial aspect of chimpanzee's brain, showing cerebral systems in terms of inhibitory activity connecting convexity and singular areas ${ }^{23}$, on neuronography experiments. (Courtesy of Arq Neuropsiquiatr, São Paulo).

Table 2, drawn on a set of 40 patients $^{26}$, afterwards enlarged to $100^{25}$, presents a revised version of the corresponding data in which we based selective lobotomy ${ }^{21}$. However, it is not on the realm of brain lesions only that such conceptions may be applied. Kleist used this way of thinking on the endogenous psychoses, showing that here the analysis of cerebral systems, or functions systems, may be brought to a refinement that leaves far back the data derived from local lesions.

Long before publishing the milestone of cerebral pathology, the Gehirn - pathologie ${ }^{10}$, he had construed the psychic systems into the leading principle for the classification of schizophrenia, a subject to which he turned in one of his last works ${ }^{11}$. This same fruitful appreciation and in the same direction, even when independently of Kleist researches we find in Leonhard's remarkable monograph on deteriorated schizophrenics ${ }^{13}$. It was also this principle that have guided our own selections of chronical schizophrenics for insulin ${ }^{19}$ or metrazol shock treatment ${ }^{20}$.

Combining the conception of brain systems with that of cerebropathogenesis, which is closely related to it, Kleist ${ }^{8,10-12}$ on the one side and Leonhard on the other ${ }^{13-15}$ have thrown a quite new light on the group of endogenous psychoses. This was not a chance happening, we believe, but the effect of using a way of reasoning and a subjective weapon that were gratifying in the hands of Wernicke but fell in discredit due to their complexity and the hard work they require as a background. Summing up, this dividing line is, as Leonhard points out, "the spirit of Wernicke and Kleist" clinical requirements is not apt to attract the psychiatrists in general, but there is no other alternative, we think, when clinical reality and precision in diagnosis, in other words, safety for the patient and steadiness for the psychiatric orientation, are to be reached. This implies leaving out the purely descriptive or phenomenological framework so popular in psychiatry of today and move towards the pathogenic dynamisms.

It was the merit of Kleist to deepen the psychopathologic analysis in order to separate the 
Table 2. Frontal lobe symptoms evoked by distant foci.

\begin{tabular}{ll}
\hline Region primarily involved & Frontal lobe symptoms \\
\hline Parieto-temporal & Delusion, mainly based on hallucinations \\
& Confabulation, irrespective of amnesia \\
& Clérambault's mental automatism, auditory-verbal or \\
& motor verbal in type \\
& Auditory hallucionations \\
& Speech disorders, as for rhythm or structure \\
& Hyperactivity, alternating with lack of initiative \\
& Delusion, chiefly based on morbid interpretation \\
& Grandeur, or expansive, delusion \\
& Aggressive behavior, oriented by delusional themes \\
& Rag-Gatherin, delusional, or meaningful \\
& Echolalia \\
& Paroxysmal loss of tonus in erect posture \\
& Gait ataxia, with no mental symptoms of frontal lobe \\
Nerebstagmus & Vertigo accompanied neither by other Menière components \\
Labirinthine area & nor by steady cerebellar signs
\end{tabular}

Research on 100 patients, verified by Blind Pneumoencephalography - 1945 (Revised in 1951 on 200 patients, with the same criterion)

several clinical patterns into a central group with definite course and outcome on the one hand, and many other entities apparently pertaining to it but indeed obeying to a quite different process, on the other. He was able, thus, to disentangle true catatonia, true hebephrenia and the deteriorating paranoid process, all of which led to a catastrophic outcome, from the benign clinical patterns which were forced into those groups due to an overindulgent criterion. In the same way the psychoses benign in course were divided into the principal groups of constitutional patterns and the other ones genetically related to them but deriving from the disposition maintained in latency: the latter ones characterized by him, provisionally, as "degeneration psychoses" 9 .

This same line of researches allowed Leonhard to make a fundamental distinction within the group of schizophrenias: one with definite patterns and genetic background - the typical forms, later on renamed systematic - and the other multiform and genetically distinct from the former - atypical or nonsystematic ${ }^{13-15}$. It is important to note that Kleist called the former groups - on slightly different ground - simple or combined forms, and the second ones extensive forms: in the first case, the process being confined into one or more systems within the same sphere, in the other coming the spreading out to another sphere. Eventhough we consider the forementioned spheres and systems of personality in a way somewhat different ${ }^{24}$, the pathogenesis of the schizophrenias - in Kleist's as well as in Leonhard's meaning - may be seen consistently to those standpoints, as we tried to summarize in Table 3.

We cannot comment here on the pathogenesis proposed on Table 3, since it would lead us too far, as regards time limitations. Some remarks are needed, however. One is that many forms assembled in the same brace under column Clinical patterns have the same pathogenesis, as far as personality sphere is concerned, but they come into clinical expression through different systems within each one sphere: column at right. On the other hand, essential differences between systematic and nonsystematic forms, sensu Leonhard's, arise from the fact that in the former only one sphere is the seat of original derangements, -while two or more spheres are struck at the same time in the nonsystematic. We believe that these assumptions may be supported by the very descriptions given 
Table 3. Assumed cerebral pathogenesis in Leonhard's schizophrenias. Within the nonsystematic group we included here Kleist's typical [ ] and extensive ( ) patterns.

\begin{tabular}{|c|c|c|}
\hline Pathogenesis & Clinical patterns & System involved \\
\hline \multicolumn{3}{|c|}{ A-Systematic forms } \\
\hline $\begin{array}{l}\text { Paranoid: paraphrenias } \\
\text { Intellectual spheres }\end{array}$ & $\begin{array}{l}\text { Incoherent, Phantastic } \\
\text { Phonemic, Confabulatory } \\
\text { Hypochondriacal, Expansive }\end{array}$ & $\begin{array}{l}\text { Intellectual } \\
\text { Conative } \\
\text { Affective }\end{array}$ \\
\hline $\begin{array}{l}\text { Catatonic } \\
\text { Conative sphere }\end{array}$ & $\begin{array}{l}\text { Speech-inactive, Speech-prompt } \\
\text { Manneristic, Parakinetic } \\
\text { Negativistic, Proskinetic }\end{array}$ & $\begin{array}{l}\text { Intellectual } \\
\text { Conative } \\
\text { Affective }\end{array}$ \\
\hline $\begin{array}{l}\text { Hebephrenic } \\
\text { Affective sphere }\end{array}$ & $\begin{array}{l}\text { Autistic } \\
\text { Shallow } \\
\text { Silly, Eccentric }\end{array}$ & $\begin{array}{l}\text { Intellectual } \\
\text { Conative } \\
\text { Affective }\end{array}$ \\
\hline \multicolumn{3}{|c|}{$B-$ Nonsystematic forms } \\
\hline $\begin{array}{l}\text { Affecte laden paraphrenia } \\
\text { Intellectual and affective spheres }\end{array}$ & $\begin{array}{l}\text { (Progressive signification psychosis) } \\
\text { (Circumscribed delusional psychosis) }\end{array}$ & $\begin{array}{l}\text { Intellectual } \\
\text { Conative }\end{array}$ \\
\hline & $\begin{array}{l}\text { [ Progressive influence psychosis] } \\
\text { (Progressive inspiration psychosis) } \\
\text { (Progressive self reference psychosis) }\end{array}$ & Affective \\
\hline $\begin{array}{l}\text { Periodic catatonia } \\
\text { Conative and affective spheres }\end{array}$ & (Iterative catatonia) & Conative \\
\hline $\begin{array}{l}\text { Schizophasia } \\
\text { Intellectual, conatice and } \\
\text { affective spheres }\end{array}$ & $\begin{array}{l}\text { [Schizophasia] } \\
\text { [Paralogical Schizophasia] } \\
\text { (Shif-like confused Schizophasia) }\end{array}$ & $\begin{array}{l}\text { Intellectual } \\
\text { Conative } \\
\text { Affective }\end{array}$ \\
\hline
\end{tabular}

independently by Kleist ${ }^{8,11}$ and Leonhard ${ }^{15}$. It may not be clear why we speak of a conative meaning in such intellectual patterns as the phonemic, the confabulatory, the paralogical schizophrenias, the influence psychosis, as well as in the shallow hebephrenia. In brief, phonemic or verbal-hallucinatory (Kleist) processes, much as the intrapsychical spelling of thoughts, would depend on the indispensable stimulation mediated by the conation - in the meaning of Comte ${ }^{4}$, Audiffrent ${ }^{2}$ and McDougall ${ }^{16}$ as well; the other disturbances reflect pathologically the same intervening of conative forces to elicit thinking processes: as global shifting in confabulation, as the sensation of being mastered, or mastering others, in influence psychosis, as a straying of the stream of thoughts in the paralogical deviation; shallow hebephrenia, on the other hand, shows a marked lack of initiative, as Leonhard points out ${ }^{15}$.

We believe that this same way of thinking may apply to other abnormal conditions more remotely related to the main group of endogenous conditions: we have in mind the neuroses and the psychopathic personalities. In the first group we think that the processes disorganizing the personality give rise to different patterns as they center on the affective, the conative or the intellectual sphere primarily. Here also it ought to be considered for the same sphere, the period of personality development in which the disturbing forces came into action: thus the difference of organizational level would account for the appearance of anxiety hysteria or of anxiety neurosis - in the affective sphere - or either the development of the hysterical character or simply an obsession neurosis, within the intellectual sphere. At the same time - Table 4 - the peculiar functions of each one sphere might explain the main resemblance between the hysteria and the corresponding neuroses. The psychopathic 
Table 4. Assumed main pathogenesis of neuroses.

\begin{tabular}{cclcr}
\hline & \multicolumn{2}{c}{ Neuroses from the stanpoint of brain pathogenesis } \\
\hline Pathogenic level & Pattern & \multicolumn{2}{c}{ Personality sphere originally involved } \\
\hline & & Affective & Conative & Intellectual \\
\cline { 3 - 5 } Actual & Neurotic reaction & Depressive & Compulsive & Obsessional trends \\
Upper & Neurosis & Anxiety & Compulsion & Obsession \\
Lower & Hysteria & Anxiety & Conversion & Hysterical character \\
\hline
\end{tabular}

Original ( A.S. ) on January $31^{\text {st }} 1959$ - Revised on December $8^{\text {th }}-1969$

Table 5. Psychopathic personalities from standpoint of brain dynamics.

\begin{tabular}{lll}
\hline Sphere & Level of disturbance & Personality type \\
\hline \multirow{2}{*}{ Conative } & Prudence & Asthenic \\
& Firmness & Unstable \\
& Courage & Explosive \\
Affective & Social feeling & Hyperthymic (with mythomanic variant) \\
& Instinctual drives & Pervert ( with mythomanic variant ) \\
\hline
\end{tabular}

Table 6. Distribution of phasic and episodic degeneration psychoses (Kleist) as for assumed brain pathogenesis

\begin{tabular}{lll}
\hline & Phasic course & Shift-like course \\
\hline Simple, monopolar patterns & Multiform, bipolar patterns & Episodic patterns \\
\hline $\begin{array}{l}\text { Hypochondriacal agitation } \\
\text { Hypochondriacal depression }\end{array}$ & $\begin{array}{l}\text { Acutte, anxious-ecstatic } \\
\text { delusional psychosis }\end{array}$ & \\
$\begin{array}{l}\text { Perplexed strangeness psychosis } \\
\text { Expansive confabulosis }\end{array}$ & $\begin{array}{l}\text { Conative pathogenesis predominant hypnic states } \\
\text { Anxious hallucinosis }\end{array}$ & \\
& $\begin{array}{l}\text { Akinetic-hyperkinetic } \\
\text { motility psychosis }\end{array}$ & \\
Ecstatic inspiration psychosis & $\begin{array}{l}\text { Intellectual pathogenesis predominant } \\
\text { Stuporous-agitated confusion }\end{array}$ & \\
& $\begin{array}{l}\text { Acute, perplexed, interpretation } \\
\text { psychosis. }\end{array}$ & Episodical twilight states
\end{tabular}

Revised (A.S.) July 23,1969.

inferiority, as we understand it, means a general deviation bearing on the affective or in the conative sphere of personality. Thus, on this pathogenetic basis we restrict the psychopathic personalities to only five groups, all of which belong to the same classification generally accepted - Table 5. Prevailing level of disorganization, deep or instinctual, upper or related to social feelings, should count for the one to be anti-social, the other accepted, within the affective sphere of personality; in the same way, the diverse interplaying of the conative forces would take account of the explosiveness, the instability or the asthenic behavior, within the conative frame of reference. 
Table 7. Leonhard's systematic and nonsystematic schizophrenias, as compared to the forms described by Kleist.

\begin{tabular}{ll}
\hline Kleist's System & Leonhard's System \\
\hline HEBEPHRENIAS & HEBEPHERNIC FORMS \\
Silly hebephrenia & Silly hebephrenia \\
Depressive hebephrenia & Eccentric hebephrenia \\
Apathetic hebephrenia & Shallow hebephrenia \\
Autistic hebephrenia & Autistic hebephrenia \\
CATATONIAS & CATATONIC FORMS \\
Negativistic catatonia & Negativistic catatonia \\
Proskinetic catatonia & Proskinetic catatonia \\
Akinetic catatonia & \\
Stereotyped catatonia & Manneristic catatonia \\
Parakinetic catatonia & Parakinetic catatonia \\
(Iterative catatonia) & [Periodic catatonia] \\
Speech-inactive catatonia & Speech-inactive catatonia \\
Speech-prompt catatonia & Speech-prompt catatonia \\
PARANOID SCHIZOPHRENIAS & PARANOID FORMS \\
Progressive somatopsychosis & Hypochondriacal paraphrenia \\
Progressive hallucinosis & Expansive paraphrenia \\
Progressive confabulosis & Confabulatory paraphrenia \\
Phantasiophrenia & Phantastic paraphrenia \\
Progressive influence psychosis & \\
Progressive inspiration psychosis & [Schizophasias] \\
PARAPHRENIAS & \\
(Circumscribed delusional psychosis) & [Affect laden paraphrenia] \\
(Progressive signification psychosis) & \\
(Progressive self reference psychosis) & \\
CONFUSED SCHIZOPHRENIAS & \\
Incoherent schizophrenia & \\
Paralogical schizophrenia & \\
Schizophasia & \\
(Shift-like confused schizophrenia & \\
\hline
\end{tabular}

This translation is taken from Fish $(1958)^{5,6}$ in separate lists. Brackets, braces and italics are ours. ( ) = Kleist's atypical, extensive forms; [ ] = Leonhards's nonsystematic schizophrenias. Italics mean Kleist's most characteristic forms.

As for the degeneration psychoses described by Kleist, we may see the likeness of the ones related to the same personality sphere pathogenetically, even when they belong to different groups genetically speaking: so, some are multiform in pattern, that is, more tainted as for heredologic background, other monopolar or pure in clinical pattern, what bespeaks of a less charged background - see Table 6. All of Kleist's patterns here considered - which were conceived in a somewhat different way -in the classification on Leonhard ${ }^{15}$ - have in common the nature of their outcome: they show a benign course, some tending to relapse but leaving no permanent trace.

Distinctive trait of schizophrenia, in Kleist's as well as in Leonhard's system, is the tendency to a progressive course and towards entering sometimes belated - into the deteriorating phase. Kleist used a complex system for the classification of the schizophrenias that he formerly described as independent entities - the hebephrenias, the catatonias, the paranoid deteriorations later on split into paranoid schizophrenias, confused schizophrenias and the paraphrenias. Some were pure forms, combined or simple, some were extensive: these are shown in Table 7, the latter in parentheses, 
Table 8. Comparison between degeneration psychosis and schizophrenia: within the latter we gave in italic the most characteristic forms and in parentheses the extensive, atypical ones. Revised (A.S.) on December 12,1974.

\begin{tabular}{|c|c|c|c|c|c|c|c|c|}
\hline \multirow[b]{4}{*}{ 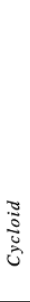 } & \multicolumn{3}{|c|}{$\begin{array}{l}\text { KLEIST's DEGENERATION PSYCHOSES } \\
\text { (Course either phasic or episodic) }\end{array}$} & & \multicolumn{4}{|c|}{$\begin{array}{c}\text { SCHIZOPHRENIA AFTER KLEIST } \\
\text { (Course rather progressive, seldon shift-like) }\end{array}$} \\
\hline & \multicolumn{8}{|c|}{ Cerebral systems that may give rise to the fundamental symptoms } \\
\hline & Affective & Active & Intellectual & \multirow{2}{*}{$\begin{array}{c}\text { SPHERE OF } \\
\text { PERSONALITY: }\end{array}$} & Affective & Active & Intellectual & \\
\hline & $\begin{array}{l}\text { Psychoses of the } \\
\text { Self: } \\
\text { Hypochondriacal } \\
\text { depression } \\
\text { Hypochondriacal } \\
\text { agitation }\end{array}$ & $\begin{array}{c}\text { Motility } \\
\text { Psychoses: } \\
\text { Akinectic } \\
\text { Hyperkinetic }\end{array}$ & $\begin{array}{l}\text { Confusion: } \\
\text { Stuporous } \\
\text { Agitated }\end{array}$ & & $\begin{array}{c}\text { Depressive } \\
\text { Silly }\end{array}$ & Apathetic & Autistic & 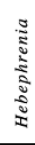 \\
\hline$\frac{\sqrt{a}}{\frac{\pi}{2}}$ & $\begin{array}{c}\text { Episodical Hypnic } \\
\text { states }\end{array}$ & $\begin{array}{c}\text { Periodical } \\
\text { morbid } \\
\text { impulsions } \\
\text { (Dypsomania) }\end{array}$ & $\begin{array}{c}\text { Episodical } \\
\text { twilight states }\end{array}$ & $\begin{array}{c}\text { ACTIVE } \\
\text { (CONATIVE) }\end{array}$ & $\begin{array}{l}\text { Negativistic } \\
\text { Proskinetic }\end{array}$ & $\begin{array}{c}\text { Akinetic } \\
\text { Stereotyped } \\
\text { Parakinetic } \\
\text { (Iterative) }\end{array}$ & $\begin{array}{l}\text { Speech-inactive } \\
\text { Speech-prompt }\end{array}$ & $\frac{0}{0}$ \\
\hline $\begin{array}{c}5 \\
5 \\
5 \\
5 \\
5 \\
3 \\
3\end{array}$ & $\begin{array}{c}\text { Acute } \\
\text { strangeness } \\
\text { psychosis } \\
\text { (perplexed) } \\
\text { Acute reference } \\
\text { psychosis } \\
\text { (anxious) } \\
\text { Acute inspirations } \\
\text { psychosis } \\
\text { (anxious) }\end{array}$ & $\begin{array}{c}\text { Acute } \\
\text { hallucinosis } \\
\text { (anxious) } \\
\\
\text { Acute } \\
\text { confabulosis } \\
\text { (expansive) }\end{array}$ & $\begin{array}{c}\text { Acute } \\
\text { Interpretation } \\
\text { psychosis } \\
\text { (perplexed) } \\
\\
\\
\text { Acute } \\
\text { Delusional } \\
\text { psychosis } \\
\text { (Anxious-Ecstatic) }\end{array}$ & INTELLECTUAL & $\begin{array}{c}\text { Progressive } \\
\text { somatopsychosis } \\
\text { Progressive } \\
\text { autopsychosis } \\
\text { Progressive } \\
\text { self reference } \\
\text { psychosis } \\
\text { Progressive } \\
\text { Inspiration } \\
\text { psychosis }\end{array}$ & $\begin{array}{l}\text { Progressive } \\
\text { hallucinosis }\end{array}$ & \begin{tabular}{|c|} 
Phantasiophrenia \\
(Progressive \\
signification \\
psychosis) \\
(Circumscribed \\
desilusion) \\
Incoherent \\
Schizophrenia \\
Paralogica \\
Schizophrenia \\
Schizophasia \\
Schizophrenia \\
(Shift-like confused \\
Schizophrenia)
\end{tabular} & 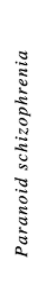 \\
\hline
\end{tabular}

the most typical among the former in italics. Leonhard considers the nonsystematic forms as genetically diverse from the systematic ones and, in addition, simplified the list of individual forms $s^{5,6,15}$. However, since both these authors take as leading principle the pathogenesis and the conception of brain systems, their classification coincide in many points and there is no special contradiction between them, as we may see in Table 7 .

Here it is to be noted that Leonhard does not relate Kleist's paralogical schizophrenia to his own schizophasia, explicitly. However, he ascribes to the derangement in thinking - including those paralogical dynamisms the main features of schizophasia. Introducing this pattern says Leonhard ${ }^{15}$ : "I could not foster the views that in schizophasia speech is troubled independently of thinking processes, as Kraepelin intended it and also Kleist admitted. It is always possible to demonstrate a disturbance in thinking, still more marked" (page 219).

Finally we would like to stress the fact that both large groups of endogenous psychoses - the schizophrenias and the degeneration psychoses - use to have many features in common: this is due, in our mind, to the fact that the same personality sphere - or the same system within each one - is involved in the morbid process. Thus, genetically they differentiate but pathogenetically they happen to remain alike when analyzed in a superficial way.

Perhaps the nonsystematic forms of schizophrenia, in the meaning of Leonhard, may stand as an intermediate between both groups. This is in accordance with the painstaking genetical researches carried out by Leonhard, which authorized him to state: "The affinity towards the cycloid psychoses comes more markedly to light from the fact that to each one of these latter curable forms corresponds one non-systematic schizophrenia. From the anxiety-bliss-psychosis (Angst-Glücks-Psychoses) comes the connection to affect laden paraphrenia; from the motility psychosis, to periodic catatonia; from the confused psychosis the one to schizophasia" (page 184) 15 $^{15}$.

Taking now the whole group of endogenous, benign, degeneration psychoses and on the other hand the total group of schizophrenias as described by Kleist and Leonhard, we find the same likeness in the main features of the diverse patterns, as confronted group by group. 
In order to render this comparison easier we assembled such conditions on Table 8, where they are arranged according to the clinical groups and the pathogenic dynamisms supposed to be at work.

As may be seen on the Table, similarity in the prevailing symptoms each one degeneration psychosis (Kleist) may share with the corresponding form of schizophrenia does not imply similarity of the clinical conditions. Quite on the contrary, if the psychiatrist does not content himself with this superficial and naive attitude of describing the pattern on phenomenological grounds only, they appear as perfectly separate and distinguishable clinical entities. In addition it is not in the least a question of irrelevant details for the construction of the diagnostic summing up. The prognosis for the outcome of the pattern itself and for the genetical implications varies from one extreme to the other as regards the degeneration psychoses and the schizophrenias. Hence, the care that the psychiatrist must devote to the differential diagnosis, which is imperative for the proper handling of the patient as a moment within the genetical stream.

\section{REFERENCES}

1. Audiffrent G. Du cerveau et de l'innervation. Paris: Dunod, 1869.

2. Audiffrent G. Des maladies du cerveau et de l'innervation. Paris: Leroux, 1874.

3. Bailey P, von Bonin G, Davis EW, Garol HW, McCulloch WS, Roseman E, Silveira A. Functional organization of the medial aspect of the primate cortex. J. Neurophysiol1944;7:51.

4. Comte A. Systeme de politique positive, 4 vols. (1851-1854). 2Ed Paris: Mathias, 1879.

5. Fish FJ. A clinical investigation of chronic schizophrenia. J Ment Sci 1958;104:34.

6. Fish FJ. Leonhard's classification of schizophrenia. J Ment Sci 1958;104:943.

7. Fulton JF. Frontal lobotomy and affective behavior. New York: Norton, 1951.

8. Kleist K. Die Auffassung der Schizophrenie als psychische Systemerkrankungen (Heredodegenerationen). Klin Wschr, 1923;21:962.

9. Kleist K. Ueber zykloide, paranoids und epileptoide Degenerationspsychosen und ueber die Frage der Degenerationspsychosen. Schw Arch Psychiat 1928;23:3.

10. Kleist K. Gehirnpathologie vornehmlich auf Grund der Kriegserfahrung. Leipzig: Barth, 1934.

11. Kleist R. La sintomatologia de las esquizofrenias a la luz de la patologia cerebral. Arch Neurobiol 1960;23:1.

12. Kleist K. Die Lokalisation im Grosshirn und ihre Entwicklung. Psychiat Neurol 1959;137:289.

13. Leonhard K. Die defektschizophrenen Krankheitsbilder. Leipzig: Thieme, 1936.

14. Leonhard K. Grundlagen der Psychiatrie. Stuttgart: Enke, 1948.

15. Leonhard K. Die Aufteilung der endogenen Psychosen. 2. Aufl. Berlin: Akademie, Verlag, 1959.

16. Magoun HW. The waking brain. Springfield: Thomas, 1958.

17. McCulloch WS. Interareal interaction of the cerebral cortex. In Bucy PC. The precentral motor cortex. Chicafo: Illinois Med, Dent Monographs, 1943.

18. McDougall W. Aufbaukraefte der Seele. Leipzig: Thieme, 1937.

19. Silveira A. Behandlung schizophrener mittels Insulin- oder Konvulsions-schocks? Klinisclier Beltrag für die Auswahl der Kranken. Zeit Neurol 1939;166:604.

20. Silveira A. 0 método de Meduna em esquizofrenicos crônicos. Fac Med São Paulo, 1941.

21. Silveira A. Lobotomy in the light of brain physiology. Lisboa: Congr Intern Psychosurg, 1948.

22. Silveira A. Discussion of Hill's report on EEG. CR Congr Mondial Psychiatrie (Paris, 1950), 1952;3:86.

23. Silveira A. Caracterização da patologia cerebral, da psicopatologia e da heredologia psiquiátrica na doutrina de Kleist. Arq Neuropsiquiatr 1959;17:102.

24. Silveira A. Esquizofrenia e psicoses degenerativas de Kleist: patogenta e psicopatologia diferenclais. Arq Neuropsiquiatr 1959;17:143.

25. Silveira A, Robortella M, Vizzotto S, Silva CP. Les renseignements que le psychiatre peut tirer de la pneumoencéphalographie. CR Congr Mondial Psychiatrie (Paris, 1950), 1952;3:293.

26. Silveira A, Silva CP, Robortella M. Contribuição para a semiologia psiquiátrica: a pneumoencefalografia. Arq Assist Psicopatas São Paulo 1947;12:5. 